\title{
Evaluation of the Effects of Ethanolic Extract of Sesamum Indicum Seeds on Sperm Morphology and Viability in Ketoconazole- Induced Testicular Damage in Male Wistar Rats
}

\author{
Yusuf $\mathrm{MK}^{1 *}$, Ibegbu $\mathrm{AO}^{1}$, Alawa $\mathrm{JN}^{1}$, Ilyas $\mathrm{MO}^{1}$ and Hammed $\mathrm{FO}^{2}$ \\ ${ }^{1}$ Department of Human Anatomy, College of Medical Sciences Ahmadu Bello University, \\ Nigeria \\ ${ }^{2}$ Department of Human Anatomy, Bauchi State University, Nigeria
}

*Corresponding author: Yusuf MK, Department of Human Anatomy, Faculty of Basic Medical

\section{Research Article \\ Volume 4 Issue 1}

Received Date: March 23, 2020

Published Date: April 13, 2020

DOI: $10.23880 /$ cprj-16000121

Sciences, College of Medical Sciences Ahmadu Bello University, Zaria, Nigeria, Email: maylkabiru2014@gmail.com

\section{Abstract}

Aim: The study was aimed at evaluating the effects of ethanolic extract of Sesamum indicum seeds on sperm morphology and viability in ketoconazole induced testicular damage in Wistar rats.

Methods: Forty eight adult male Wistar rats were divided into eight Groups of six rats each. Groups 1,2,3,4,5,6,7 and 8 were administered $1 \mathrm{ml}$ of normal saline, $100 \mathrm{mg} / \mathrm{kg}$ body weight (bwt) of Ketoconazole only, $500 \mathrm{mg} / \mathrm{kg}$ bwt of ethanolic extract of sesamum indicum (EESI) seeds then $100 \mathrm{mg} / \mathrm{kg}$ bwt of Ketoconazole, $100 \mathrm{mg} / \mathrm{kg}$ bwt of Ketoconazole then $250 \mathrm{mg} / \mathrm{kg}$ body weight of EESI seeds, $100 \mathrm{mg} / \mathrm{kg}$ bwt of Ketoconazole then $500 \mathrm{mg} / \mathrm{kg}$ bwt of EESI, $100 \mathrm{mg} / \mathrm{kg}$ body weight of Ketoconazole then $0.36 \mathrm{mg} / \mathrm{kg}$ body weight of Mesterolone, $0.36 \mathrm{mg} / \mathrm{kg}$ body weight of Mesterolone, $500 \mathrm{mg} / \mathrm{kg}$ body weight of EESI respectively. All administrations were carried out orally once per day. The sperm smears were collected for semen analyses.

Result: A significant increase in the abnormalities of sperm morphology and viability respectively were noted in the group administered ketoconazole alone (Group 2) compared with other experimental Groups ( $\mathrm{P} \leq 0.05)$.

Conclusions: The administration of ethanolic extract of Sesamum indicum appeared to have minimized the damages and sperm deaths caused by ketoconazole which may be due to its androgenic properties.

Keywords: Evaluation; Sesamum; Sperm; Morphology; Viability Ketoconazole; Rats

Abbreviations: EESI: Ethanolic Extract of Sesamum Indicum; SEM: Standard Error of Mean; ANOVA: Analysis of Variance; SPSS: Statistical Package for Service Solution; SE: Standard Error; CI: Confidence Interval.

\section{Introduction}

Adverse effects of drugs among other factors are known to affectnormal body functions and most especially reproductive health [1]. One of such Drugs is Ketoconazole, an antifungal drug [2]. Ketoconazole is packaged pharmaceutically in the form of tablets, creams and injections and has been reported to inhibit the stimulation of testicular testosterone production by Human Chorionic Gonadotropine in a dose dependent manner [3]. Steroids such as dihydrotestosterone and estradiol are equally, selectively displaced from serumbinding globulin by ketoconazole [4]. The suppression of testicular testosterone synthesis and the displacement of oestrogen from sex hormone binding globulin may decrease the androgen/oestrogen ratio of the blood and contributes to 


\section{Clinical Pathology \& Research Journal}

the development of gynaecomastia that has being reported in some ketoconazole treated patients [4]. Administration of ketoconazole alters sperm indices

Over the years, there has been increased scientific research to minimize the health hazards potentiated by some toxins and this was done on phytochemicals extracted from plant species [5]. In an effort to stem the contraindications of some of these synthesized drugs, plant medicine (phytomedicine) has been used as alternatives in many parts of Africa and the rest of the world. One of such phyto-medicine is Sesame indicum. Sesame seeds are reported to contain high level of unsaturated fatty acids such as Oleic acid$38.84 \%$ and linolenic acid-46.26\% [6]. Trace elements such as Calcium, Iron, Magnesium, Zinc, Copper and Phosphorous were also reported to be contained in it [7]. Sesame seeds are also reported to be rich in phyto estrogenic lignans which is an important phytochemical known to man [8]. The entire sesame plant is very valuable and serves as staple food in most ethnic groups in North-Central and South-Western part of Nigeria [9].

\section{Materials and Method}

\section{Seed Procurement and Identification}

$470 \mathrm{~g}$ of Sesamum indicum seeds were obtained from Samaru market-Zaria, Kaduna State, Nigeria and authenticated in the herbarium of the Department of Biological Sciences, Ahmadu Bello University Zaria and assigned voucher no. 4 . The seeds were macerated using
$95 \%$ ethanol to obtain the extract with a yield weight of $46.42 \mathrm{~g}$ in solvent form.

\section{Drugs and Reagents}

$200 \mathrm{mg}$ of ketoconazole tablets and $25 \mathrm{mg}$ of Tablet Provirone (Mesterolone) manufactured by Divine New Favour Pharmaceuticals (Anambra State) and Bayers Pharmaceuticals (United Kingdom) with batch Nos. 82339737 and 4008500060056 and NAFDAC Nos. A4-2186 and 04-1300, respectively, were purchased from Micro novo Pharmaceutical Company Plc. Kano, Kano State, Nigeria.

\section{Methods}

\section{Extraction of Sesame seeds}

$470 \mathrm{~g}$ of sesame seed was macerated in a maceration apparatus. The sesame seeds were poured into $2 \mathrm{ml}$ maceration apparatus (Pyrex) and the seeds coats were manually removed. The macerated seeds were later transferred into a three and half (3.5) L beaker containing $95 \% \mathrm{v} / \mathrm{v}$ of ethanol to cause the removal of flavanoids and lignans. It was stirred and left for six hours to allow the extraction of polar substances. The supernatant was sieved off using a metallic sieve and the filtrate was collected into a separate beaker. The filtrate was collected into an evaporating dish with the use of a spatula and placed on a water bath, heated to a temperature of $60^{\circ} \mathrm{C}$ to completely remove the ethanol. The extract was kept for eighteen hours to allow for evaporation to take place. The yield weight of the extract was $46.42 \mathrm{~g}$ in solvent form (Table 1 \& Figure 1 ).

\begin{tabular}{|c|c|c|}
\hline $\mathbf{S} / \mathbf{N}$ & GROUPS & DOSAGE/DURATION OF ADMINISTRATION \\
\hline 1 & Normal Control & $1 \mathrm{ml}$ of Normal Saline daily for the experimental period \\
\hline 2 & Abnormal Control & $\begin{array}{l}\begin{array}{l}\text { Ketoconazole (100 mg/ kg bwt) once daily for five (5) days (14th -18th day of } \\
\text { experiment). }\end{array} \\
\end{array}$ \\
\hline 3 & Prophylactic Group & $\begin{array}{l}500 \mathrm{mg} / \mathrm{kg} \text { bwt of ethanolic extract of sesame indicum seeds for (13 days) }+100 \mathrm{mg} / \mathrm{kg} \\
\text { bwt of ketoconazole for (5) five days. }\end{array}$ \\
\hline 4 & $\begin{array}{l}\text { Therapeutic Low Dose } \\
\text { Group }\end{array}$ & $\begin{array}{l}100 \mathrm{mg} / \mathrm{kg} \text { bwt of Ketoconazole for (5) five days }+250 \mathrm{mg} / \mathrm{kg} \text { bwt of ethanolic extract of } \\
\text { sesame indicum seeds once daily for five (5) days and thirteen (13) days respectively. }\end{array}$ \\
\hline 5 & $\begin{array}{l}\text { Therapeutic High Dose } \\
\text { Group }\end{array}$ & $\begin{array}{l}100 \mathrm{mg} / \mathrm{kg} \text { bwt of Ketoconazole for (5) five days }+500 \mathrm{mg} / \mathrm{kg} \text { bwt of ethanolic extract of } \\
\text { sesame indicum seeds for thirteen days. }\end{array}$ \\
\hline 6 & $\begin{array}{l}\text { ketoconazole and } \\
\text { Mesterolone }\end{array}$ & $\begin{array}{l}\text { Ketoconazole (100 mg/ kg bwt) for five days }+0.36 \mathrm{mg} / \mathrm{kg} \text { bwt of Mesterolone once daily } \\
\text { for thirteen days }\end{array}$ \\
\hline 7 & Mesterolone & $0.36 \mathrm{mg} / \mathrm{kg}$ bwt of Mesterolone once daily for thirteen days. \\
\hline 8 & $\begin{array}{l}\text { Sesame seeds extract } \\
\text { only }\end{array}$ & $500 \mathrm{mg} / \mathrm{kg}$ bwt of ethanolic extract of Sesamum indicum seeds only for thirteen days. \\
\hline
\end{tabular}

All administrations were carried out orogastrically.

Table 1: Groups of the Animals and their Administrations. 


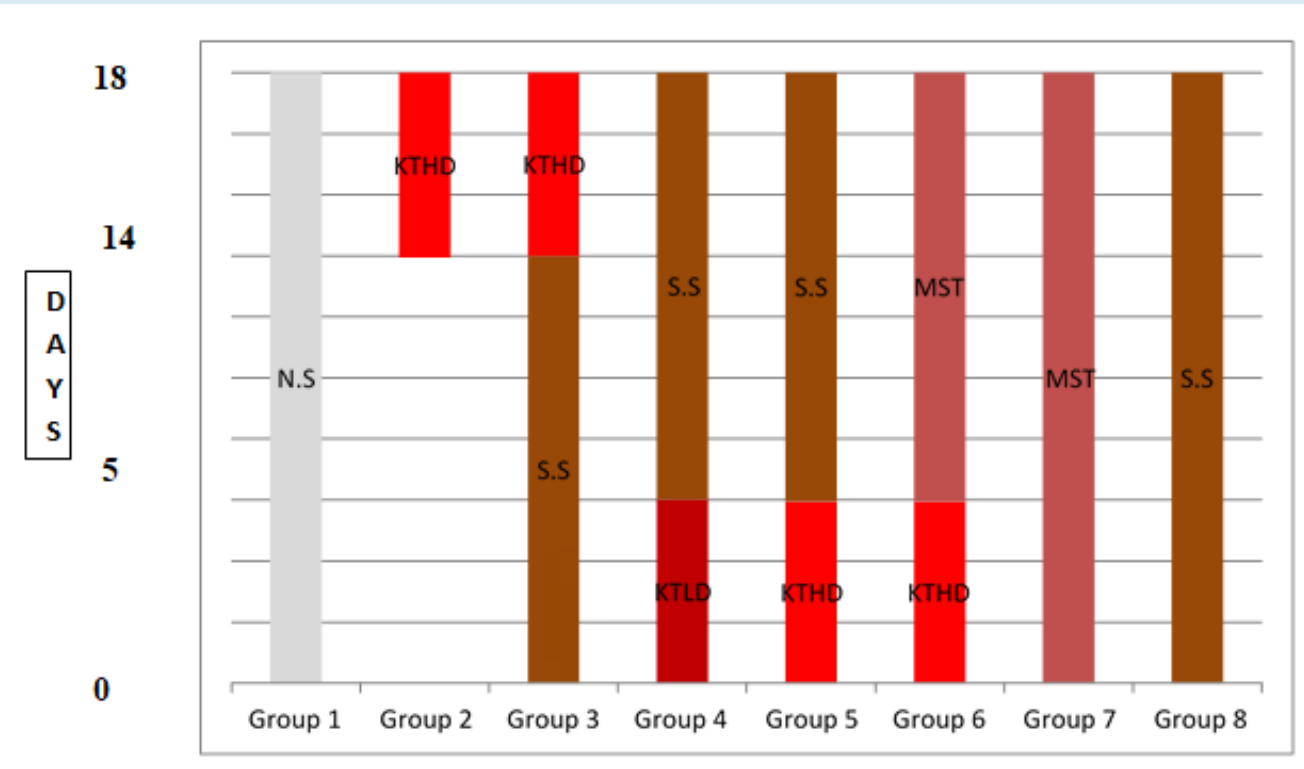

Figure 1: Histogram representing drug administration.

NS; Normal Saline, KTHD; Ketoconazole high dose, SS; Sesamum Seeds, KTLD; Ketoconazole low dose group, MST; Mesterolone.

\section{Experimental Procedure}

The $\mathrm{LD}_{50}$ the ethanolic extract of sesamum indicum seeds in wistar rats was done and was found to be above $5000 \mathrm{mg} /$ $\mathrm{kg}$ bwt meaning that the extract is safe. The equivalent dose of the drugs and the sesame seed extract; in ml (milliliters) were derived using the formulae:

$$
\text { Volume }(\mathrm{ml})=\frac{\text { Dose } \mathrm{x} \text { weight }(\mathrm{kg})}{\text { Stock concentration }}
$$

The equivalent dose in $\mathrm{ml}$ of ethanolic extract of Sesamum indicum seeds was calculated as follows:500 mg/ $\mathrm{kg}$ bwt $=500 \mathrm{mg}=1000 \mathrm{~g}$, the average weights of the rats at the time of commencement of the experiment was 180g; therefore, the administrable dose $(\mathrm{x})$ for a rat that weighed $180 \mathrm{~g}$ was calculated as:

$$
\text { Volume }=\frac{500 \mathrm{mg} / \mathrm{kg} \times 0.180 \mathrm{~kg}}{128.3 \mathrm{mg} / \mathrm{ml}}
$$

$0.70 \mathrm{ml}$ was obtained as the volume for a dose of $500 \mathrm{mg} / \mathrm{kg}$ bwt which was the high dose group. Similar method was used to calculate the volume of the low dose group $(250 \mathrm{mg} / \mathrm{kgbwt}$ ) and the value $0.35 \mathrm{ml}$ was obtained. Tablet mesterolone was prepared as $25 \mathrm{mg}$ and it was the recommended dose for an adult person (Average weight $=$ $70 \mathrm{~kg})$.
From above, the administrable dose per $1 \mathrm{~kg}$ was calculated as shown below. $25 \mathrm{mg}$ (mesterolone) $=70 \mathrm{~kg}$ $=70000 \mathrm{~g}$; therefore, the dose $(\mathrm{x})$ for every $1 \mathrm{~kg}=1000 \mathrm{~g}$ is calculated as follows:

$$
\mathrm{x}=\frac{25 \mathrm{mg} \times 1,000}{70,000}=0.36 \mathrm{mg} / \mathrm{kg} \mathrm{bwt}
$$

From above, the administered dose for a rat that weighed $180 \mathrm{~g}$ was calculated as:

$$
\frac{0.36 m g x 180 g}{1000 g}=0.065 m g
$$

Earlier, it was stated that the packaged form of Mesterolone is $25 \mathrm{mg}$ per tablet. The tablet was dissolved in $10 \mathrm{ml}$ of distilled water to obtain a concentration of $2.5 \mathrm{mg} /$ $\mathrm{ml}$. from above, $2.5 \mathrm{mg}$ is contained in $1 \mathrm{ml}, \mathrm{x} \mathrm{ml}$ will contain $0.065 \mathrm{mg}$. By calculation, $\mathrm{X}=0.065 / 2.5=0.026 \mathrm{ml}$, therefore, $0.026 \mathrm{ml}$ which contains $0.065 \mathrm{mg}$ of Mesterolone tablet was measured using a micro pippet and was administered to the rats.

\section{Animal Sacrifice}

The animal were put to death via perfusion technique and the epididymis of the left testis was excised and immersed in $5 \mathrm{ml}$ of formal saline for the determination of the sperm parameters. 


\section{Clinical Pathology \& Research Journal}

\section{Statistical Analysis}

All data obtained were expressed as mean \pm standard error of mean, (SEM). One way analysis of variance (ANOVA) was used to compare the mean difference between and within the groups and a P-value of $\leq 0.05$ was considered statistically significant, a post-Hoc was carried out to indicate were significant difference lie. Statistical analysis was carried out using statistical package for Service Solution (SPSS) Version 20.

\section{Semen Analysis}

\section{Sperm Cell Concentration/Count}

Sperm cell concentration refers to the total number of spermatozoa per unit volume of semen and it is a function of the number of spermatozoa emitted and the volume of fluid diluting them [10]. Sperm cell count is the total number of spermatozoa in the entire ejaculate and it is obtained by multiplying the sperm concentration by the semen volume
[10].

\section{Determination of Sperm Concentration}

The 1:20 method was adopted for the present study. In this procedure, $50 \mathrm{ml}$ of liquefied semen was mixed with $950 \mathrm{ml}$ of diluents. The diluents were constituted with the following reagents: $50 \mathrm{~g}$ of sodium carbonate (NaHCO3), $10 \mathrm{ml}$ of $35 \%(\mathrm{v} / \mathrm{v})$ formalin and, optionally, $0.25 \mathrm{~g}$ of trypan blue and making up the solution to a final volume of $1000 \mathrm{ml}$.

\section{Assessment of Sperm Numbers in the Counting Chambers}

Sperm number was assessed in both chambers of the haemocytometer. The haemocytometer was examined with phase-contrast optics at $\times 400$ magnifications and at least 200 spermatozoa were counted in each replicate; this was to achieve an acceptable low sampling error. The central grid (Number 5 in Figure 2) of one side of the improved Neubauer chamber was first assessed on row by row as indicated below.

\section{Image of haemocytometer grid}
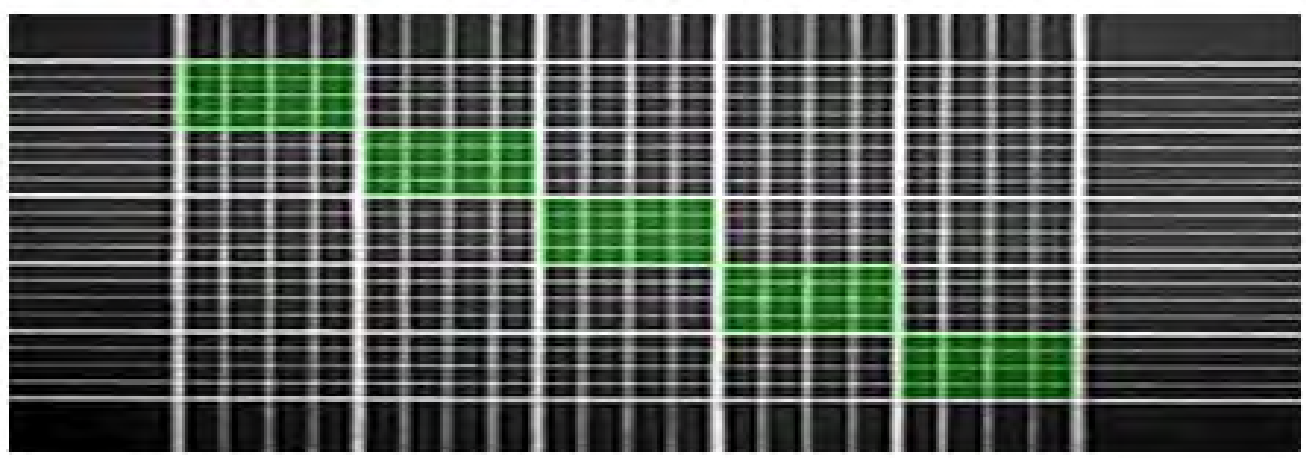

Figure 2: Low Magnification View of the haemocytometer grid system.

Note that each side of the haemocytometer has an identical grid system consisting of 25 large squares in which each large square is divided into 16 smaller squares [3]. Counting was continued until at least 200 spermatozoa were observed and a complete row of five large squares was examined. Counting was done by complete rows; and was not stopped in the middle of a row. When 200 spermatozoa were not observed in the five rows of the central grid, counting was continued in the rows of 4 large squares of the two adjacent grids no. 4 and 6 in Figure 2 a note of the number of rows assessed to reach at least 200 spermatozoa was made to avoid mix up in the counting. The same number of rows was counted from the other chamber of the haemocytometer.
The number of spermatozoa and rows were tallyed with the aid of a laboratory counter.

A switch was made to the second chamber of the haemocytometer to perform the replicate count on the same number of rows (the same volume) as the first replicate was used. The sum and difference of the two numbers were calculated. The acceptability of the difference from each shows the maximum difference between the counts that is expected to occur in $95 \%$ of samples because of sampling error alone. The two replicates were determined from Table 2. 


\begin{tabular}{|c|c|c|c|c|c|}
\hline Total (N) & Sampling error (\%) & Total (N) & Sampling error (\%) & Total (N) & Sampling error (\%) \\
\hline 1 & 100 & 25 & 20 & 85 & 10.8 \\
\hline 2 & 70.7 & 30 & 18.3 & 90 & 10.5 \\
\hline 3 & 57.7 & 35 & 16.9 & 95 & 10.3 \\
\hline 4 & 50 & 40 & 15.8 & 100 & 10 \\
\hline 5 & 44.7 & 45 & 14.9 & 150 & 8.2 \\
\hline 6 & 40.8 & 50 & 14.1 & 200 & 7.1 \\
\hline 7 & 37.8 & 55 & 13.5 & 250 & 6.3 \\
\hline 8 & 35.4 & 60 & 12.9 & 300 & 5.8 \\
\hline 9 & 33.3 & 65 & 12.4 & 350 & 5.3 \\
\hline 10 & 31.6 & 70 & 12 & 400 & 5 \\
\hline 15 & 25.8 & 75 & 11.5 & 450 & 4.7 \\
\hline 20 & 22.4 & 80 & 11.2 & 500 & 4.5 \\
\hline
\end{tabular}

Table 2: Rounded Sampling Error (\%), According to Total Number of Spermatozoa Counted according to WHO (2010).

Note: If the difference is less $\leq 10 \%$ of the total count of the two preparation, then its acceptable. If however, it is greater $10 \%$ of the total count of the two preparations, then it is unacceptable [3].

The difference between the two counts fell within the acceptable limits, so the count was accepted and the concentration was calculated as enumerated. The hemocytometer is $0.1 \mathrm{~mm}$ deep and the 25 large squares represent an area of 1 square $\mathrm{mm}$. The volume above the 25 squares shown is $0.1 \mu \mathrm{l}$, but only 5 squares are required, by mathematical calculation, the volume in the five square is calculated as: $(0.1 / 5=0.02)$. To determine how many sperm would have been in $1.0 \mathrm{ml}$, calculate as Let " $y$ " represent total number of sperm cell count in all five squares. By implication, $0.02 \mu \mathrm{l}$ contains y number of SCC. $1.0 \mathrm{ml}=1000 \mu \mathrm{l}$ will contain $\mathrm{z}$ number of SCC. $\mathrm{z}$ is calculated as (sum of SCC in 5 square) $\times 1000 / 0.02$ the value obtained is expressed in terms of numbers $/ \mathrm{ml}$. To get the concentration of the original sperm sample multiply by the dilution factor.

The equation was used to convert the counts in 5 squares to concentration $/ \mathrm{ml}$ :

Concentration $/ \mathrm{ml}=$ (Dilution Factor) (Count in 5 squares) $\left(0.05 \times 10^{6}\right)$

By convention, sperm concentration is usually expressed in terms of sperm X $10^{6} / \mathrm{ml}$.

Total sperm cell count $=$ sperm cell concentration $\times$ volume of the ejaculate.

Table 2 was used to determine the acceptable or nonacceptable percentage error of average count. This is because the precision of the estimate of sperm number depends on the number of spermatozoa counted. In a Poisson distribution, the standard error (SE) of a count $(\mathrm{N})$ is the square root $(\mathrm{N})$ and the $95 \%$ confidence interval $(\mathrm{CI})$ for the number of spermatozoa in the volume of semen is approximately $\mathrm{N} \pm$ $1.96 \times \mathrm{N}$ (or $\mathrm{N} \pm$ approximately $2 \times \mathrm{N}$ ). When 100 spermatozoa were counted, the SE is 10 (100), and the $95 \% \mathrm{CI}$ is $80-120$ $(100 \pm 20)$. When 200 spermatozoa were counted, the SE is $14(200)$, and the $95 \% \mathrm{CI}$ is $172-228(200 \pm 28)$. When 400 spermatozoa were counted, the SE is $20(400)$ and the $95 \% \mathrm{CI}$ is $360-440(400 \pm 40)$. The sampling errors can be conveniently expressed as a percentage of the count $(100 \times$ $(\mathrm{N} / \mathrm{N}))$. These are shown in Table 2.

\section{Sperm Cell Viability using Eosin Negrosin Stain}

The percentage of live spermatozoa was assessed by identifying those with an intact cell membrane, from dye exclusion method. The dye exclusion method is based on the principle that, damaged plasma membranes, such as those found in non-viable (dead) cells, allow entry of membraneimpermeant stains.

\section{Eosin-Nigrosin Smear Observed In Bright Field Optics}

Spermatozoa with dark purple (D1) heads are considered dead (membrane-damaged). While a spermatozoon with white heads (L) or light purple heads are considered live (membrane intact) as shown in plate I.

\section{Estimation of Viability}

The total number of spermatozoa with intact cell membrane in the ejaculate is of biological significance because the cell membranes of such sperm cells are impermeate to eosin negrosine stain which is a standard method of ascertaining viable sperm cells. The total number 
of viable sperm cells is obtained by multiplying the total number of spermatozoa in the ejaculate by the percentage of membrane-intact cells.

\section{Results}

\section{Sperm Morphology}

The result of sperm morphology presented in Table 3 showed that the sperm morphology for Groups 4 and 5 was significantly increased when compared with Groups 1 and 2 $(\mathrm{P}<0.05)$, and the sperm morphology of animals in Group 3 was significantly decreased $(\mathrm{P}<0.05)$ when compared with Groups 4 and 5. While the sperm morphology of animals in Groups 4 and 5 was significantly increased $(\mathrm{P}<0.05)$ when compared with Group 3. There was no significant difference between the sperm morphology in animals in Groups 5 and
6.

The result in plate 1 , showed normal sperm in Group 1 while Group 2, showed different sperm abnormalities the result of sperm morphology of animals in the Control Group 1 , show normal sperm as shown in plate $2 \& 2$, while Group 2 animals, show some sperm abnormalities such as head, tail abnormalities, viable and non-viable sperms as shown in plate 3 and 4, Plate 5, show sperm cells from animals in Group 3, with some viable and non-viable sperm. Group 4 animals' show some sperm cells with tail abnormalities as shown in plate 6 while Group 5 animals, show some sperm cells with head and mid piece deformities as shown in plate VII. Group 6 animals show many normal sperm cells as shown in plate 8 , while plate 9 and 10 , indicated sperm cells with coiled tail from Group 7 animals and many sperm cells with normal sperm morphology from Group 8 animals.

\begin{tabular}{|c|c|c|c|c|c|c|c|}
\hline \multirow[b]{2}{*}{ Group } & \multirow[b]{2}{*}{$\mathbf{N}$} & \multicolumn{4}{|c|}{ Morphology } & \multicolumn{2}{|c|}{ Viability } \\
\hline & & HA & NA & TA & NS & $\mathbf{V}$ & NV \\
\hline & & Mean \pm SEM & Mean \pm SEM & Mean \pm SEM & Mean \pm SEM & Mean \pm SEM & Mean \pm SEM \\
\hline 1 & 6 & $36.67 \pm 1.63^{\text {abcdefg }}$ & $0.00 \pm 0.00^{\mathrm{g}}$ & $0.00 \pm 0.00^{\mathrm{fg}}$ & $63.33 \pm 1.63^{\text {abcdf }}$ & $72.00 \pm 0.58^{\text {bdef }}$ & $27.67 \pm 0.49^{\text {bdef }}$ \\
\hline 2 & 6 & $48.67 \pm 0.21^{* \mathrm{bfg}}$ & $0.00 \pm 0.00^{g}$ & $0.00 \pm 0.00^{\mathrm{fg}}$ & $51.17 \pm 0.31^{* \text { bcfg }}$ & $69.33 \pm 0.49^{\mathrm{bdf}}$ & $30.83 \pm 0.40^{\text {bdef }}$ \\
\hline 3 & 6 & $16.17 \pm 1.42^{\text {*acde }}$ & $2.83 \pm 2.83$ & $1.50 \pm 1.02^{\mathrm{fg}}$ & $82.33 \pm 0.88^{* \text { *acde }}$ & $83.50 \pm 1.88^{* \text { acde }}$ & $17.33 \pm 1.76^{\text {*acdeg }}$ \\
\hline 4 & 6 & $55.00 \pm 3.15^{* b f g}$ & $1.00 \pm 0.00^{\mathrm{g}}$ & $0.00 \pm 0.00^{\mathrm{fg}}$ & $29.17 \pm 3.52^{* a b d e f g}$ & $72.67 \pm 3.74^{\text {bdef }}$ & $27.50 \pm 4.26^{\text {bdef }}$ \\
\hline 5 & 6 & $53.00 \pm 0.58^{* \mathrm{bfg}}$ & $0.00 \pm 0.00^{\mathrm{g}}$ & $0.00 \pm 0.00^{\mathrm{fg}}$ & $46.83 \pm 0.60^{* \mathrm{bcfg}}$ & $54.83 \pm 0.60 *$ abcf & $44.83 \pm 0.60^{* a b c f g}$ \\
\hline 6 & 6 & $53.00 \pm 0.73^{* b f g}$ & $0.00 \pm 0.00 \mathrm{~g}$ & $0.00 \pm 0.00 \mathrm{fg}$ & $52.67 \pm 2.73^{\mathrm{bcfg}}$ & $59.67 \pm 1.84^{* \mathrm{bcf}}$ & $42.50 \pm 1.02^{* a b c f g}$ \\
\hline 7 & 6 & $21.33 \pm 2.94^{* a c d e}$ & $0.00 \pm 0.00^{g}$ & $5.83 \pm 1.92^{* a b c d e}$ & $74.33 \pm 1.93^{\text {*acde }}$ & $87.00 \pm 2.18^{* a c d e}$ & $13.67 \pm 2.16^{\text {*acdeg }}$ \\
\hline 8 & 6 & $19.33 \pm 2.65^{* \text { *acde }}$ & $7.67 \pm 3.75^{* \text { acdef }}$ & $5.83 \pm 1.22^{* \text { abcde }}$ & $73.33 \pm 4.14^{\text {acde }}$ & $72.67 \pm 3.23^{\text {bdef }}$ & $29.83 \pm 3.32^{\text {bdf }}$ \\
\hline
\end{tabular}

HA (Head Abnormality) NA (Neck Abnormality) TA (Tail Abnormality) NS (Normal Sperm) V (Viable Sperm) NV (Non-Viable) *abcdefg= Groups $1,2,3,4,5,6$, 7\& 8 respectively differs significantly $(\mathrm{P} \leq 0.05)$.

Table 3: Sperm Indices of Morphology and Viability in the Experimental Animals.

\section{Neck Abnormality}

The result showed that there was no significant difference in the neck abnormalities of the sperm cells between Groups 1 and 2. There was no significant difference in the neck abnormalities between Groups 3, 4, 5 and Groups 1 and 2 while no significant difference among Groups 3, 4 and 5 and no significant difference was observed between Groups 5 and 6 as shown in Table 3.

\section{Tail Abnormality}

From the Table 3, the result showed that no significant difference was observed between Groups 3, 4 and 5 when compared with the Control Group 1 and Group 2. While there was no significant difference in the tail abnormalities between Groups 3, 4 and 5.

\section{Normal Sperm}

The result showed that normal sperm in Group 5 was significantly decreased when compared with Group 1, while no significant difference was observed between Groups 5 and 2. Normal sperm in Group 3 was significantly decreased when compared with Groups 4 and 5. (P $\leq 0.05$ ) Normal sperm cells Group 4 was significantly decreased when compared with Group 5. While normal sperm cells in Group 5 was significantly different from those of Groups 3 and 4 (P $\leq 0.05$ ) as shown in Table 3 . 


\section{Clinical Pathology \& Research Journal}

\section{Viability}

The results from Table 3 showed that the sperm viability in Group 3 was significantly increased $(\mathrm{P}<0.05)$ when compared with Groups 1 and 2, while the viability in Group 4 was significantly decreased when compared with Groups 1 and $2(\mathrm{P} \leq 0.05)$. The result from Table 3 showed no significant difference between Groups 1 and 2, while sperm viability in Group 3 was observed to be significantly increased when compared with Groups 1 and 2, and Group 4 was not significantly different from Groups 1 and 2. Group 5 was significantly decreased when compared with Groups 1 and 2 . ( $\mathrm{P} \leq 0.05)$. Group 3 was significantly decreased when compared with Groups 4 and 5; while Group 4 was significantly different when compared with Groups 3 and 5. Group 5 was significantly different when compared with Groups 3 and 4. While no significant difference was observed between Groups 5 and 6 as shown in Table 3

\section{Non Viability}

The result from Table 3 showed that, non-viable sperms in Group 3 was significantly decreased when compared with Groups 1 and $2 ;(P \leq 0.05)$. While no significant difference was observed between Group 4 and Groups 1 and 2 respectively. Non-viable sperms in Group 5 were significantly increased when compared with Groups 1 and 2 and non-viable sperms in Group 3 were significantly decreased when compared with Groups 4 and 5; $(P \leq 0.05)$ Group 4 was significantly different when compared with Groups 3 and 5 ( $\mathrm{P} \leq 0.05)$. Group 5 was significantly decreased when compared with Groups 3 and $4(\mathrm{P} \leq 0.05)$ while no significant difference was observed between Groups 5 and 6 (Figures 3-12).

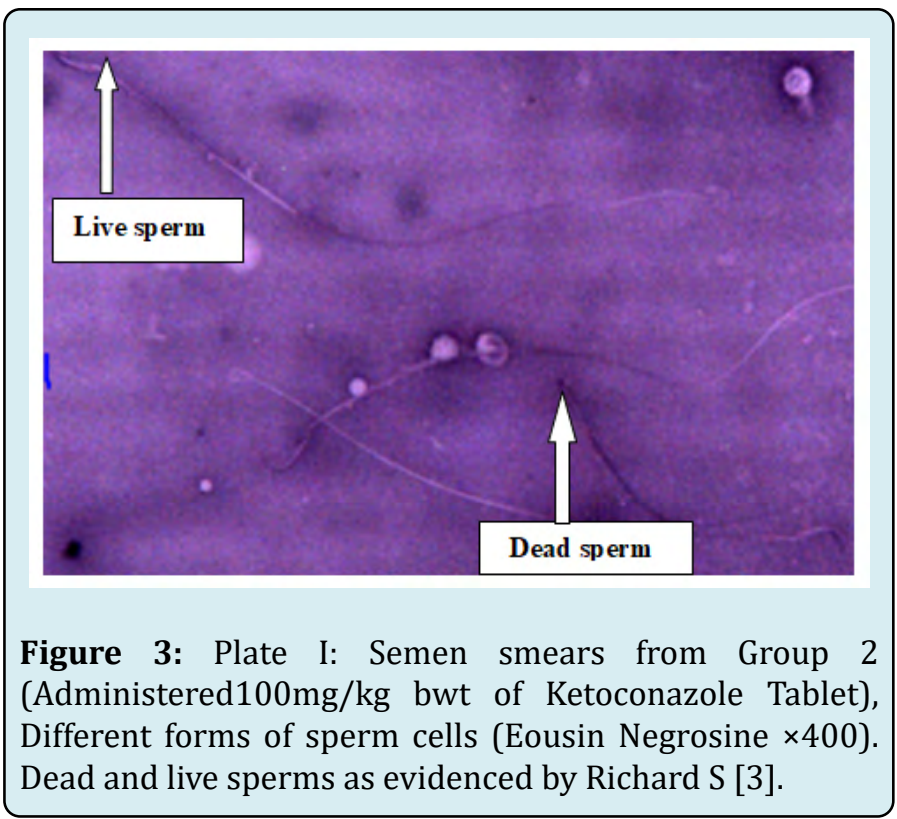

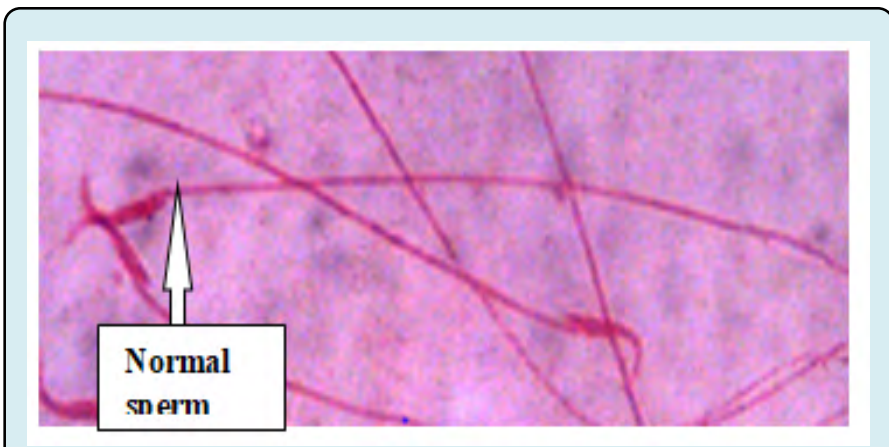

Figure 4: Plate II: Semen smears from Group 1 ( $1 \mathrm{ml}$ of Normal saline for 18 days), Normal sperm cell morphology (Eosin stain at $\times 400)$. Normal sperm as evidenced by Richard S [3].

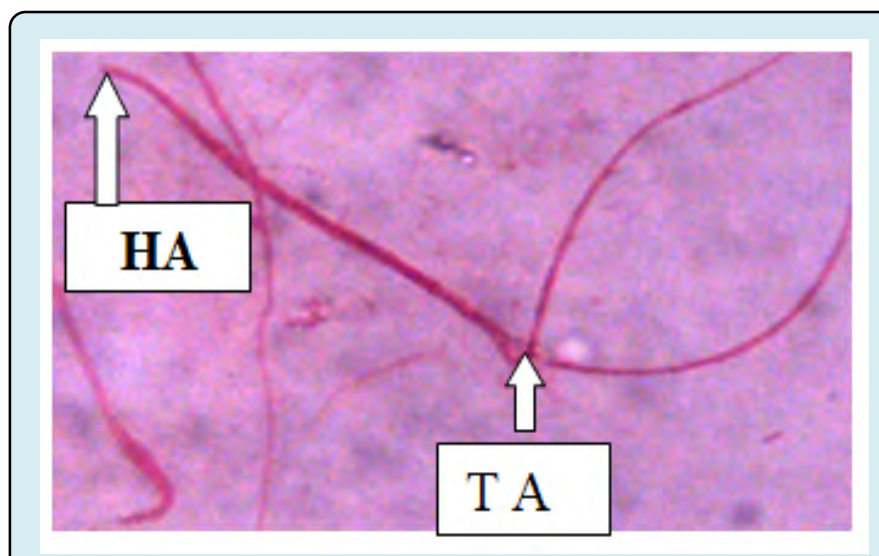

Figure 5: Plate III: Semen smears from Group $2(100 \mathrm{mg} /$ kg bwt of Ketoconazole Tablets for five days), Head (HA) and tail (TA) abnormalities (Eosin stain $\times 400$ ), Head and Tail abnormalities as evidenced by Richard $S$ [3].

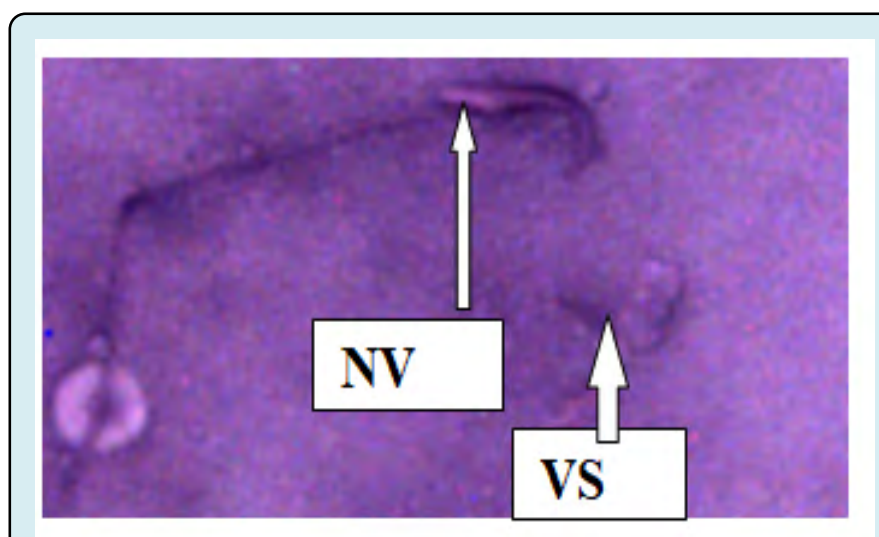

Figure 6: Plate IV: Semen smears from group $2(100 \mathrm{mg} /$ Kg bwt of Ketoconazole Tablet for five days) viable (VS) and non-viable (NV) sperm cells (Eousin- Negrosin $\times 400$ ). 


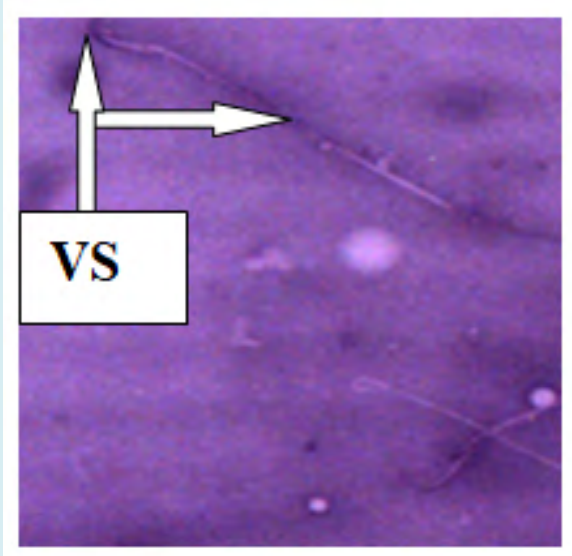

Figure 7: Plate V: Semen smears from Group 3 (500mg/ Kg bwt of ethanolic extract of Sesamum indicum seeds for thirteen days and $100 \mathrm{mg} / \mathrm{Kg}$ bwt of Ketoconazole Tablet for five days) viable sperm cells (VS) (Eousin-Negrosin $\times$ 400)

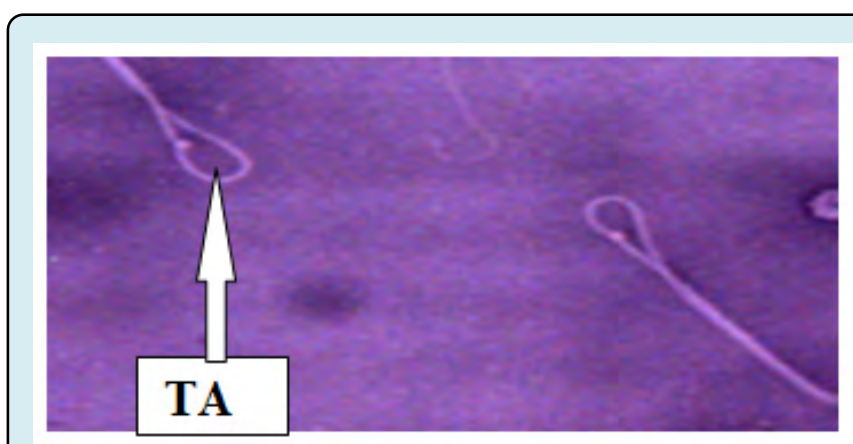

Figure 8: Plate VI: Semen smears from Group 4 (100mg/ Kg bwt of Ketoconazole Tablet for five days and 250mg/ Kg bwt of Ethanolic Extract of Sesamum indicum seeds for thirteen days) Tail Abnormalities (TA) (Eousin- Negrosin $\times 400$ ).

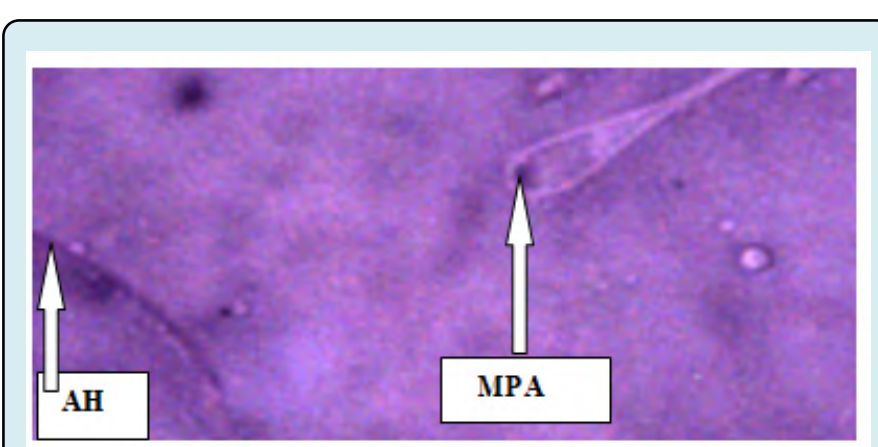

Figure 9: Plate VII: Semen smears from Group $5(100 \mathrm{mg} /$ Kgbwt of Ketoconazole Tablet for five days and 500mg/ Kg bwt of Ethanolic Extract of Sesamum indicum seeds for thirteen days), Head (HA) and Mid Piece Abnormalitiesities (MPA) (Eousin- Negrosin stain $\times 400$ ).

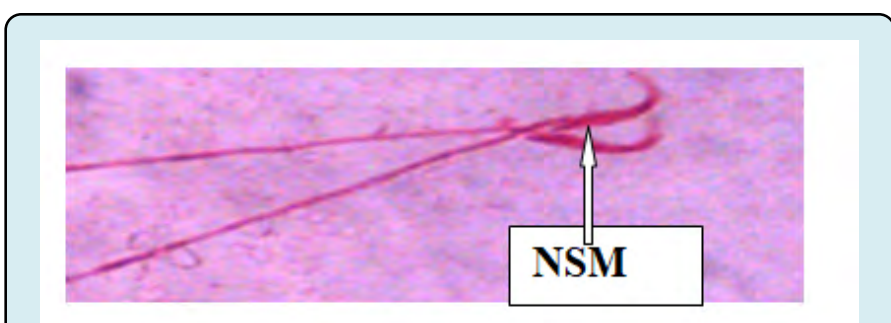

Figure 10: Plate VIII: Semen smears from Group $6(100 \mathrm{mg} /$ Kg bwt of Ketoconazole Tablets for five days and $0.36 \mathrm{mg} /$ Kg bwt Mesterolone Tablet for thirteen days) Normal sperm morphology NSM (Eosin stain $\times 400$ ).

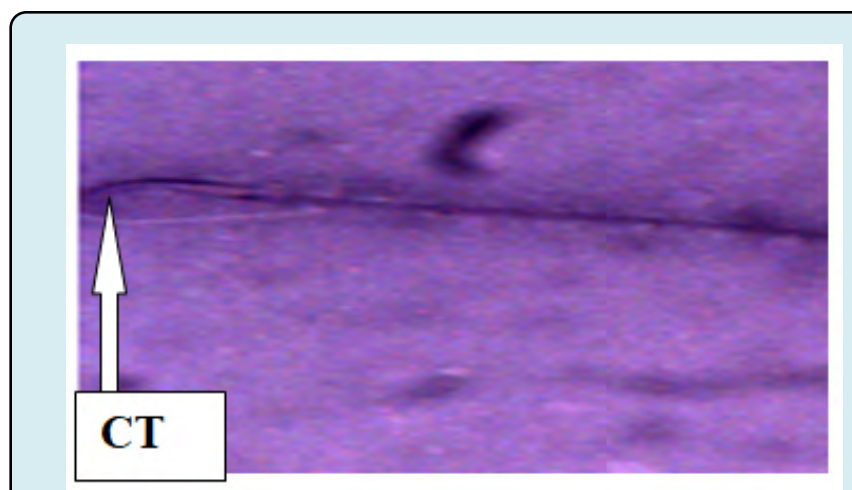

Figure 11: Plate IX: Semen smears from Group 7 (0.36mg/ $\mathrm{kg}$ bwt of Mesterolone Tablet for thirteen days) coiled tail (CT) (Eousin Negrosin stain $\times 400$ ).

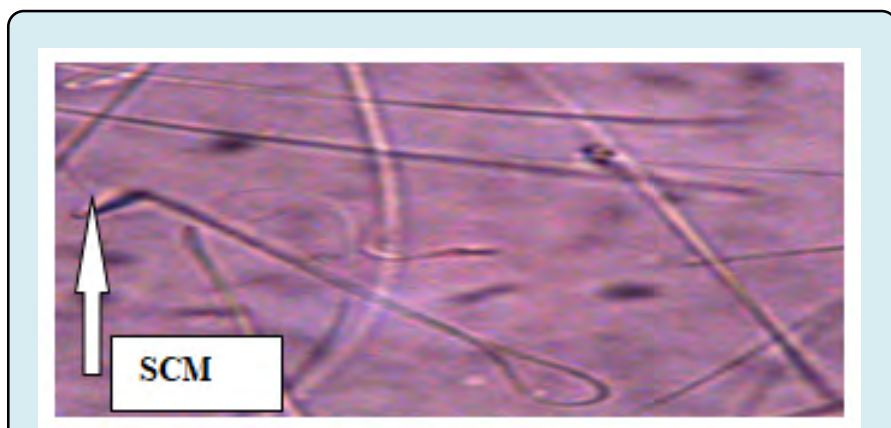

Figure 12: Plate X: Semen smears from Group $8(500 \mathrm{mg} /$ $\mathrm{Kg}$ bwt of Ethanolic Extract of Sesamum indicum seeds) sperm cell morphology (SCM) (Normal saline $\times 400$ ).

\section{Discussion}

From the present study, it was observed that ketoconazole induced sperm cell damage such as head, neck and tail abnormalities and reduction of viable sperm cells. This was noted in the morphology and number of viable and non-viable sperm cells in the ketoconazole administered Group alone which resulted in decreased sperm viability. This observation was in line with the work of Amin A [2], who observed that ketoconazole induced testicular damages in male Wistar rats by reducing the sperm indices and serum testosterone 


\section{Clinical Pathology \& Research Journal}

level. Bhasin S, et al. [11] in his work on hormonal effects of ketoconazole, reported that the measurement of circulating precursor of testosterone suggested that ketoconazole may have inhibited testosterone synthesis primarily by inhibiting the activities of multiple enzymes such as 17, 20 desmolase in the testosterone biosynthetic pathway. This suggested that multiple enzymes needed for testosterone production in the present study were also inhibited by ketoconazole administered group which consequently led to a decrease in the numbers of viable sperm cell produced.

Vawdal AL, et al. [12] had also reported that daily treatment of Wistar rats for up to ninety days caused decrease in sperm numbers, increase in the number of abnormal sperms. From the present research, a reduction in the number of viable sperm cells in Group 2 were observed; this was characterized by uptake of eosin negrosin stain by some sperm cells which indicated sperm cell mortality. Nonviable sperm cells picked up eosin negrosin stain because; the integrity of their impermeate cell membrane has being compromised [3]. This observation was also in line with the work of Amin A [2], who observed that ketoconazole alters sperm cell viability.

From the present study, a range of morphological abnormalities were observed as some sperm cells had absence of head, reduced to no tail and neck abnormalities. These observations were in keeping with the work of Vawdal AL, et al. [12], who reported that daily treatment of ketoconazole in Wistar rats caused increased proportion of abnormal sperm cells. The administration of ethanolic extract of Sesamum indicum appeared to have minimized the damages caused by ketoconazole in testes which may be due to its androgenic properties [13].

\section{Conclusion}

The administration of ethanolic extract of Sesamum indicum appeared to have minimized the damages caused by ketoconazole in testes which may be due to its androgenic properties.

\section{Significance of the study to Humans}

Scientific research has proved that the DNA composition of Wister rats (Rat models) body metabolism and physiology only differs from that of humans by $0.5 \%$. This implies that, whatever result is obtained from the rat models, there is a $99.5 \%$ chance that the same result will be obtained in humans. The results obtained from this research therefore, means that, intake of ethanolic extract of Sesamum indicum seeds in a proportionate dose (mg/kg body weight) with what was administered to the rat models in humans medicating on ketoconazole for certain ailments can help minimise it's adverse effects as seen on the micrographs and table of sperm variable that were analysed.

\section{Recommendation}

A hormonal assay should be conducted in further studies to ascertain the level of increase in testosterone.

\section{References}

1. Izegbu MC, Ojo MO, Shittu LA (2005) Clinico-pathological Patterns of Testicular Malignacies in Ilorin, Nigeria- a report of 8 cases. J Cancer Res Ther 1(4): 229-231.

2. Amin A (2008) Ketoconazole-induced testicular Damage in rats reduced by Gentiana extract. Exp Toxicol Pathol 59(6): 377-384.

3. Richard S (2015) Male Infertility Human Sperm Morphology Fixed and stained human sperm Advanced fertility Centre of Chicago sperm pictures- Male infertility. Human sperm morphology fixed and stained human sperm pictures from the IVF lab.

4. Grosso DS, Boyden TW, Pamenter RW, Johnson DG, Stephen DA, et al. (1983) Ketoconazole inhibition of testicular secretion of testosterone and displacement of steroid hormones from serum transport proteins. Antimicrob Agents Chemother 23(2): 207-212.

5. Bankole MA, Shittu LA, Ahmed TA, Bankole MN, Shittu RK, et al. (2007) Synergistic Antimicrobial Activities of phytoestrogen in crude extract of two sesame species against some common Pathogenic Microorganisms. Afr J Tradit Compliment Altern Med 4(4): 427-433.

6. Nzioku JM (2009) Chemical composition on the seeds and oil of sesame (Sesame indicum L.) grown in CongoBrazzaville. Advanced J Food and Science Techn 1(1): 6-11.

7. Obiajunwa EI, Adebiyi FM, Omode PE (2005) Determination of essential minerals and trace elements in Nigerian sesame seeds using TXRF Technique. Pakistan J Nutrition 4 (6): 393-395.

8. John B, Anton JE, Alexie A, Thompson T, Chris S, et al. (2004) Human micro RNA targets: PLOS Bio 2(7): 363.

9. Akpan IG, Idowu AA, Misani SM (2006) Collection and Evaluation of Sesame (Sesamum Spp) germplasm in Nigeria. Advanced J Food and Science Techn pp: 59-62.

10. WHO (2010) WHO Laboratory manual for examination and processing of human semen. World Health Organisation, $5^{\text {th }}$ (Edn.), pp: 28-700. 
11. Bhasin S, Sikka S, Fielder T, Moriah U, Leivan HB, et al. (1986) Hormonal effects of ketoconazole in vivo in male rat: mechanism of action. Endocrinology 118 (3): 12291232.

12. Vawdal AI, Davies AG (1986) An investigation into the effects of ketoconazole on testicular function in Wistar
Rats. European Journal of Endocrinology 111(2): 246251.

13. Amado JA, Pesquera C, Gonzalez EM, Otero M, Freijanes J, et al. (1990) Successful treatment with ketoconazole of Cushing's syndrome in pregnancy. Postgrad Medi J 66(773): 221-223. 